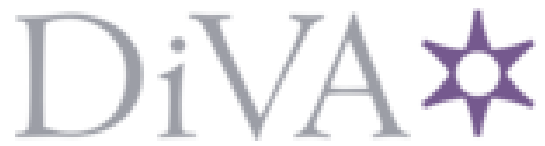

http://www.diva-portal.org

Preprint

This is the submitted version of a paper published in e-Service Journal.

Citation for the original published paper (version of record):

Rose, J., Göbel, H., Cronholm, S., Holgersson, J., Söderström, E. et al. (2019)

Theory-Based Design Principles for Digital Service Innovation

e-Service Journal, 11(1): 1-30

https://doi.org/10.2979/eservicej.11.1.01

Access to the published version may require subscription.

N.B. When citing this work, cite the original published paper.

Permanent link to this version:

http://urn.kb.se/resolve?urn=urn:nbn:se:his:diva-1769o 


\title{
Theory-based design principles for digital service innovation
}

\begin{abstract}
The article establishes theory-based design principles for constructing tools and methods for developing innovative digital services. The research method is developed from process advice offered for this task, in the context of design science. We define the objectives for the design task (solution objectives), identify and justify suitable kernel theories (service design, open innovation, service-dominant logic), and derive the principle normative elements of the chosen theories. Convergences and contradictions in the normative elements are analysed in relation to the method design task, and the prescriptive elements are synthesised into six core design principles. Implications for both the method design task, and research and practice in general are drawn.
\end{abstract}

Keywords: design principles, design science, service design, digital services, open innovation, service-dominant logic

\section{Introduction}

The concept of service has had considerable significance for research, practice, and society at large (Vargo \& Lusch 2008; Vargo \& Lusch 2016; Vargo \& Lusch 2004; Chesbrough 2011). A feature of internet-enabled societies is the redesign of existing services into digital variants, where rapid developments in information and communication technologies (ICT) drive the move to online service (Taherdoost et al., 2014), and where ICT is an indispensable component of innovative and high-quality service (Barrett et al. 2015; Lusch \& Nambisan 2015). ICT also enables the invention of entirely new services (for instance software as a service) and new delivery mechanisms (for instance digital platforms such as the Android app store). Easier access to broader markets facilitated by the internet drives the adaptation of current service offerings to more heterogeneous needs. In an environment where user requirements are diverse and segmented, and services provided in ecosystems rather than by individual firms, organisations need to focus on service and value co-creation, and innovating IT-enabled services along both primary and adjacent value chains. Many companies are moving their focus away from physical products and concentrating instead on co-creating service by involving actors in the service ecosystem. One challenge is for organisations to think beyond their traditional ways of working and see also what is not there - 'firms can be innovative with what exists, just as they can be innovative with what does not exist' (Berry \& Lampo 2000). Service ecosystems also favour open styles of innovation (Chesbrough 2003), in which innovation is not driven in-house by dominant market leaders, but created in cooperation with the providers of other ecosystem components. Service orientation is also prevalent in public sector organisations, though here core technologies have remained relatively stable during the digitisation of service (Coreynen et al. 2017). E-government has traditionally focused on providing digital improvements of existing manual paper-based services with some degree of service integration (for instance in the creation of national service portals), but with little room for innovation (Janowski 2015), and minor changes to back-office work systems. Service innovation is defined as 're-bundling of diverse resources that create novel resources that are beneficial (i.e., value experiencing) to some actors in a given context;' (Lusch \& Nambisan 2015 p.161). Value is primarily determined by the service users (customers, citizens, businesses, non-profit organisations), but service providers must also anticipate benefits if they are to use resources to create new services. We use the term digital service innovation to encapsulate these developments in thinking about service, 
covering both public and private organisations (as much e-government as e-commerce); both ICT developments and accompanying changes in work routines and processes; both the digitalization of existing services and the invention of entirely new ones; both the modernisation of existing value chains and the creation of new digital ones.

Since digital service innovation has developed rapidly, the design tools, methods and frameworks which practitioners use to envision and develop digital services also need to develop (Cronholm \& Göbel 2017). For instance, conventional system development methods are not focused on innovation, assuming that the existing manual process will be automated (Rose 2010). Participatory methods follow the same pattern where users are included as representatives or advisors (Marti \& Bannon 2009; Miller 1993) but without including an explicit innovation perspective. Conventional business development methods such as the business model canvas Osterwalder \& Pigneur (2010) neither focus on digital enablers nor follow a modern service perspective. We can also observe that perspectives in service science such as service-dominant logic (e.g. Vargo \& Lusch 2016), though based on excellent theoretical grounding, lack prescriptive guidance for application in the ICT domain. Some service design methods emphasise co-creation but lack an innovation perspective. In practice, digital service innovation is a focal point for organisations in their move to digitalisation; however, the development of such services has been conducted using a multitude of different approaches stemming from historical and practical considerations, but usually without a relevant contemporary theoretical foundation.

Using the arguments set out above, the authors obtained funding for the Innoserve (Innovative Digital Services) project. The funding supports the construction of a theory-based method for digital service innovation enabling value for service users (customers, clients, citizens), and incorporating the interests of the service provider. A theory-based method requires the selection of theories and an understanding of how to use them for method building, so our research objective for this article is to construct a set of necessary and sufficient theory-based design principles, which can provide the theoretical foundation for new methods (or method components) for the development of innovative digital services. Since the research objective implies a construction intent, a design science approach is adopted. Design principles establish, at a high-level of abstraction, aspects of what a design or a design method ought to do when instantiated in detail. Thus a necessary and sufficient set of design principles can govern the development of a full-blown method or method components including design tools, frameworks, models, and technological rules. Design science requires a theoretical foundation for constructing artefacts, and one way of providing this is to derive design principles from relevant theory, usually known as kernel theory (here service design, open innovation, service-dominant logic) (Gregor and Jones 2007). As a more specific research method, we follow (Rose et al. in review) which describes a four-step process for developing theory-based design principles. This is described in the next section. The remainder of the article describes the enactment of the four steps; formulating the design solution objectives, identifying kernel theories, deriving normative and prescriptive elements from the kernel theories, and refining and organising these elements into a necessary and sufficient set of design principles. The resulting design principles are presented and the implications for research and practice discussed. The article forms part of a larger design science project which should construct a design method for digital service innovation, but these wider objectives are a later stage of our research, and are not discussed further in this article. 


\section{Research approach}

The overall research approach for the article is design science (Walls et al. 1992; March \& Smith 1995; Gregor \& Jones 2007; Gregor \& Hevner 2013). Design science research should produce a 'theory ingrained' artefact (Sein et al. 2011) and theory used for this purpose is known as kernel theory. One common output from design science research is known as design theory (Gregor 2002); however, our work focuses on normative or prescriptive guidance for design derived from theory. This is commonly formulated as theory-based design principles. Gregor \& Hevner (2013) class this kind of design knowledge as a level 2 contribution: nascent design theory (knowledge as operational principles). Van den Akker (1999) gives a precisely articulated description of a design principle formulated in terms of characteristics, procedures, and the arguments that link them: 'if you want to design intervention $\mathrm{X}$ (for the purpose/function $\mathrm{Y}$ in context $\mathrm{Z}$ ), then you are best advised to give that intervention the characteristics $\mathrm{A}, \mathrm{B}$, and $\mathrm{C}$ (substantive emphasis), and to do that via procedures K, L, and M (procedural emphasis), because of arguments $\mathrm{P}, \mathrm{Q}$, and R.' Table 1 shows the process for deriving theory-based design principles from kernel theory articulated by (Rose et al. in review). 


\begin{tabular}{|l|l|l|}
\hline step & explanation & $\begin{array}{l}\text { common design science } \\
\text { practice }\end{array}$ \\
\hline $\begin{array}{l}\text { Formulate solution } \\
\text { objectives }\end{array}$ & $\begin{array}{l}\text { The objectives of the proposed } \\
\text { design should be clear enough } \\
\text { to guide the choice of kernel } \\
\text { theories }\end{array}$ & $\begin{array}{l}\text { Research questions or } \\
\text { objectives, design objectives, } \\
\text { short textual statements of } \\
\text { design purpose }\end{array}$ \\
\hline Identify kernel theories & $\begin{array}{l}\text { Since there are often many } \\
\text { competing theoretical } \\
\text { explanations of phenomena, } \\
\text { the optimal theory base for the } \\
\text { solution must be determined }\end{array}$ & $\begin{array}{l}\text { Literature survey, identifying } \\
\text { seminal contributions, } \\
\text { individual theory contributions } \\
\text { with excellent fit to solution } \\
\text { objectives, sometimes just } \\
\text { convenience. Several } \\
\text { kernel theorise usually } \\
\text { involved, often related or } \\
\text { connected in minor theoretical } \\
\text { development }\end{array}$ \\
\hline $\begin{array}{l}\text { Derive normative and } \\
\text { prescriptive theory } \\
\text { elements }\end{array}$ & $\begin{array}{l}\text { Where kernel theories do not } \\
\text { offer clear prescriptions that } \\
\text { can guide design, these must } \\
\text { be abstracted or derived }\end{array}$ & $\begin{array}{l}\text { Expressed in different ways: } \\
\text { rules, requirements, principles, } \\
\text { levels, with different forms of } \\
\text { expression: textual, tabular or } \\
\text { diagrammatic }\end{array}$ \\
\hline $\begin{array}{l}\text { Refine and organise } \\
\text { elements as theory- } \\
\text { based design principles }\end{array}$ & $\begin{array}{l}\text { The design prescriptions } \\
\text { should be organised in an } \\
\text { integrated form which is both } \\
\text { necessary and sufficient to } \\
\text { guide the design }\end{array}$ & $\begin{array}{l}\text { Either design principles (short } \\
\text { statements that guide practice), } \\
\text { or design theory (a novel } \\
\text { theory configuration that } \\
\text { guides, but is also tested by } \\
\text { design) }\end{array}$ \\
\hline
\end{tabular}

Table 1. A general process for deriving theory-based design principles from kernel theory (Rose et al. in review)

Table 2 gives the general process adapted to our specific task: developing theory-based design principles for digital service innovation. 


\begin{tabular}{|l|l|l|}
\hline step & our research practice & research output \\
\hline $\begin{array}{l}\text { Formulate solution } \\
\text { objectives }\end{array}$ & $\begin{array}{l}\text { Define the overall goal of the } \\
\text { eventual design artefact, and } \\
\text { decompose into well-defined solution } \\
\text { objectives }\end{array}$ & $\begin{array}{l}\text { Design goals + solution } \\
\text { objectives and definitions }\end{array}$ \\
\hline $\begin{array}{l}\text { Identify kernel } \\
\text { theories }\end{array}$ & $\begin{array}{l}\text { Choose contemporary branches of } \\
\text { theory aligned with solution } \\
\text { objectives, identify well-aligned } \\
\text { seminal contributions, select for } \\
\text { relevance, researcher experience and } \\
\text { community visibility, through a } \\
\text { process of critical questioning }\end{array}$ & $\begin{array}{l}\text { Selection of service design, } \\
\text { service-dominant logic and } \\
\text { open innovation theory areas, } \\
\text { and identification of seminal } \\
\text { contributions from }\end{array}$ \\
\hline $\begin{array}{l}\text { Derickdorn, Chesbrough and } \\
\text { and prescriptive } \\
\text { theory elements }\end{array}$ & $\begin{array}{l}\text { Analyse the seminal contributions, } \\
\text { extract major theory propositions, } \\
\text { consider characteristics, procedures } \\
\text { and linking arguments, adapt to } \\
\text { digital service innovation context and } \\
\text { express as normative prescriptions }\end{array}$ & $\begin{array}{l}\text { 22 normative prescriptions } \\
\text { derived from the seminal } \\
\text { contributions, grouped by } \\
\text { theory }\end{array}$ \\
\hline $\begin{array}{l}\text { Refine and organise } \\
\text { elements as theory- } \\
\text { based design } \\
\text { principles }\end{array}$ & $\begin{array}{l}\text { Analyse overlaps, convergences and } \\
\text { contradictions between prescriptions } \\
\text { from the previous step, synthesise in } \\
\text { an economical set of necessary and } \\
\text { sufficient design principles, express } \\
\text { in the Van den Akker formulation }\end{array}$ & $\begin{array}{l}\text { A set of six design principles } \\
\text { for digital service innovation, } \\
\text { expressed in the Van den } \\
\text { Akker formulation }\end{array}$ \\
\hline
\end{tabular}

Table 2. The specific process for the research task: developing theory-based design principles for digital service innovation.

The steps were carried out in a series of face to face researcher workshops, supported by online administration meetings, and the research outputs (particularly solution objectives and design principles) were further refined in three workshops with expert service designers. The workshops contained both design exercises and focus group discussions using an interview protocol based on emerging solution objectives and design principles. Two service development companies and a Swedish municipality were involved, involving eight participants (external participants at CIO level or equivalent). The workshops consisted of three interrelated parts: 1) an introductory interview regarding the current state with respect to service development within the organisation, 2) a workshop part where the basic principles for service design, service-dominant logic and open innovation are put into an exemplifying context, and 3) a follow up interview to catch the respondents' impression of the design principles discussed. A set of questions, were each question was anchored in one or more of the design principles, was asked in order to understand to what extent these were possible to meet. The results were transcribed and organised according to each heading in the question list with thematic (content) analysis, and fed back into the researcher discussion.

The following four sections describe the process and outputs for each of the four steps specified in this research method. A numbering system guides the reader in following the 
theoretical argument, so that solution objectives (SO1-n) are traceable to kernel theories, kernel theory elements (Service Design SD1- $n$, Open Innovation OI1- $n$ and ServiceDominant Logic $S D L 1-n)$ traceable to theory convergences (C1-n) and theory convergences traceable to the eventual design principles. Analysis techniques from table 2 are picked out in italics as they reoccur throughout the analysis steps.

\section{Solution objectives}

The overall aim of the Innoserve research project is to create a method for designing innovative digital services with a combined customer/user and supplier/developer perspective. The research team's initial workshops focused on solution objectives (SO) describing the overall requirements for the method artefact (Heinrich \& Schwabe 2014), which were refined during the project. The starting point was the project description. The solution should encourage the development of service value for both provider and user, implying a focus on the service aims and objectives, early visualisation on the service in use and its likely user evaluation, as well as the design activities. These objectives imply some element of co-creation. The whole service should be considered, rather than just its digital implementation and it should be meaningful for different types of actors in the design process, in both public and private sectors (the project contains both types of organisations). Innovation should be directly considered to avoid the perceived problem of simply automating existing service procedures. However, the co-creation aspect disposed towards some form of openness in the innovation style. Some elements of the project description could be translated directly into solution objectives, for instance: ' ...[service developers] often focus on technology and hardware and software, instead of the customer's expected value from the service in use' (Innoserve project description). This statement was transformed into two high level SOs: SO2 and SO3. Other solution objectives were derived through discussion and refined through consultation in the practitioner workshops. Figure 1 gives the solution objectives.

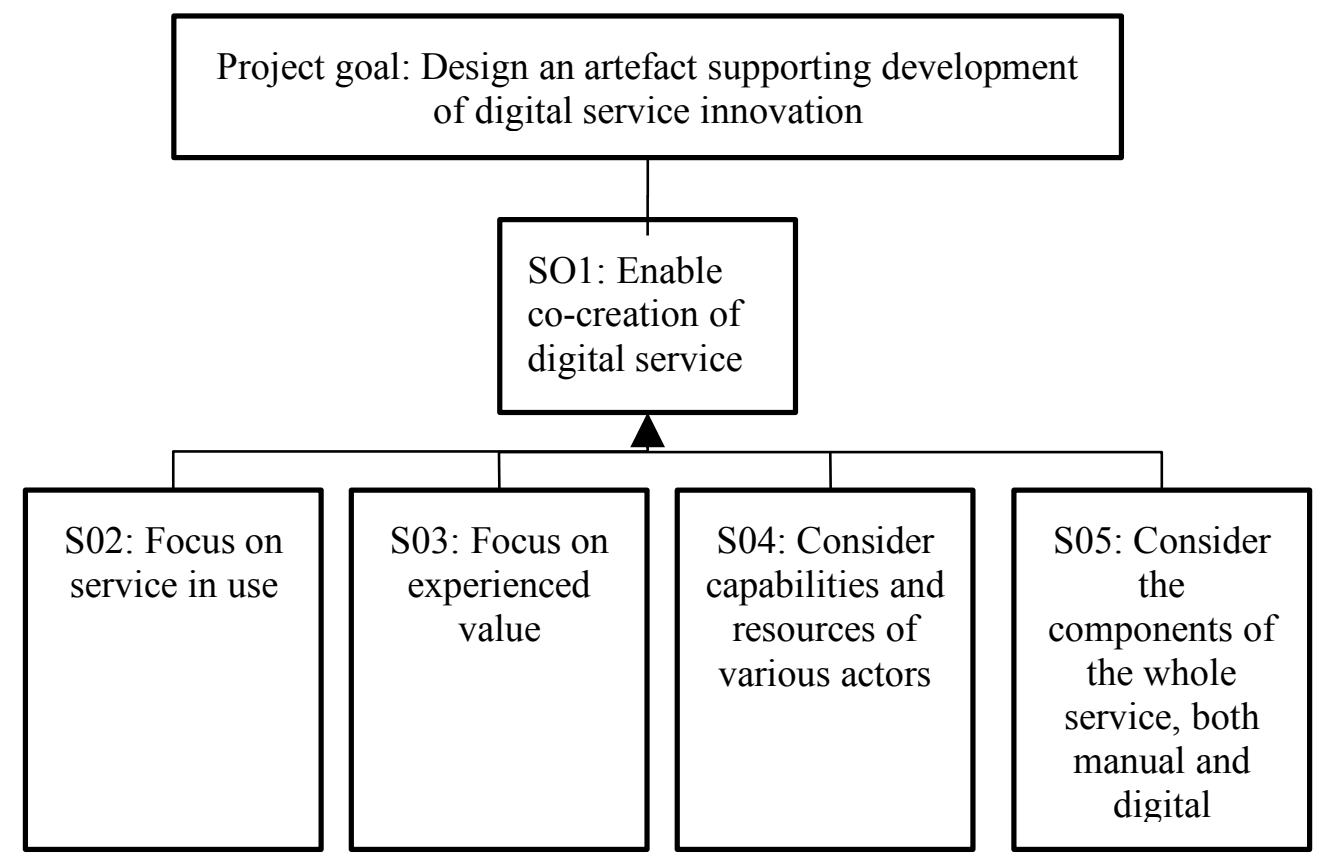

Figure 1. The Solution Objectives supporting the overall project goal.

The solution objectives enabled the formation of a common understanding of both project and artefact goals. 


\section{Identification and justification of kernel theories}

The identification and justification of kernel theories are guided by the solution objectives (relevance - defined as correspondence between the principle tenets of the theory and the solution objectives). The solution objectives point at various scientific fields including (amongst others): (digital) innovation, service marketing, service science, e-services and parts of e-commerce and e-government. Since the number of contributions in these fields (Google Scholar hits $>10 \mathrm{~m}$ ) precludes literature review as a feasible selection technique, we decided to select seminal theories from these fields in such a way as to cover the solution objectives. Seminal theories make good kernel theories because of their many citations and secondary literatures, and a degree of acceptance and continuing development in their respective research communities They also normally have a degree of spill over into practice, giving them high visibility. Visibility is an important element of design-oriented theory work because it increases the chances of understanding and acceptance by practitioners. A third selection criterion was our own experience; choosing familiar theories with which we had previously worked, in fields where we had relatively wide experience simplifies the learning curve and strengthens our confidence in fulfilling the research purpose. It also increases the chances of being able to make meaningful theoretical analysis and choices, such as focusing on key propositions and reformulating descriptive elements as normative statements. An early researcher workshop generated a list of relevant theory areas included: co-creation and open innovation, design and innovation, digital service innovation, service design, servicedominant logic, social sustainability and open design. Many of the core theories from these fields are developed outside the IS community. According to Gregor and Hevner (2013), kernel theories from outside the IS knowledge base often provide new ideas for artefact design. A further workshop iterated and critiqued the theory choice (questioning) before it was approved as a kernel theory for the design exercise. Based on the solution objectives, we selected the three kernel theories: service design, open innovation and service-dominant logic. Open innovation and service-dominant logic have prominent seminal contributors. However, this is less obvious for service design, where we conducted a small backup literature study. Table 3 indicates the seminal theories and their coverage of the solution objectives. 


\begin{tabular}{|l|l|l|l|}
\hline Theory area & $\begin{array}{l}\text { Major theory } \\
\text { proposition }\end{array}$ & $\begin{array}{l}\text { Seminal authors and } \\
\text { works }\end{array}$ & $\begin{array}{l}\text { Solution objective } \\
\text { coverage }\end{array}$ \\
\hline Service design & $\begin{array}{l}\text { Offers an } \\
\text { interdisciplinary } \\
\text { perspective on how } \\
\text { to design service }\end{array}$ & $\begin{array}{l}\text { (Stickdorn \& } \\
\text { Schneider 2012) }\end{array}$ & SO1, SO2-4 \\
\hline Open innovation & $\begin{array}{l}\text { Contrasts new open } \\
\text { innovation forms } \\
\text { with earlier closed } \\
\text { internal firm } \\
\text { innovation }\end{array}$ & $\begin{array}{l}\text { (Chesbrough 2003; } \\
\text { Chesbrough 2006) }\end{array}$ & SO1, SO3-5 \\
\hline $\begin{array}{l}\text { Service-dominant } \\
\text { logic }\end{array}$ & $\begin{array}{l}\text { Offers a new service } \\
\text { centred way of } \\
\text { thinking for firms } \\
\text { which contrasts with } \\
\text { traditional goods } \\
\text { (product) dominated } \\
\text { thinking }\end{array}$ & $\begin{array}{l}\text { Lusch 2016; Vargo } \\
\text { \& Lusch 2008) }\end{array}$ & SO2-5 \\
\hline
\end{tabular}

Table 3. Kernel theories, seminal works and solution objective coverage.

\section{Derivation of normative theory elements}

The next part of the work involved the writing of literature analyses. In the case of service design, a small literature search was carried out to identify highly relevant sources, but in the case of open innovation the seminal contributions authored by Chesbrough with various coauthors were reviewed, and for service-dominant logic the research articles of Vargo and Lusch were analysed. The researchers, working in groups of two, identified the theory tenets with the highest relevance for the design work, documenting them in short (5 page) literature reviews. Many of the theories covered have strong normative elements, and include some advice for practitioners which can be adopted and/or adapted. In accordance with the guidelines for formulating design principles suggested by Van den Akker (1999), we analysed characteristics, procedures and linking arguments. Characteristics are desired outcomes in the eventual designed artefact (service), procedures are activities that should be carried out to achieve such characteristics, and arguments link procedures to eventual characteristics, explaining why particular actions might result in particular desired outcomes. With the written reviews available we conducted further workshop activities to abstract the most relevant theory elements to our solution objectives, and we reformulated these in our own words as short normative design principles. The following three sections give condensed versions of the theory analyses, followed in each case by our derived prescriptive elements which can be thought of as candidate design principles.

\section{Service Design}

As described by Stickdorn \& Schneider (2012), Service Design (SD) should be seen as an interdisciplinary approach combining different research fields concerned with how to design service. In its essence SD relies on five basic core characteristics: 1) User-centred, 2) Cocreative, 3) Sequencing, 4) Evidencing and 5) Holistic. In short, User-centred and Co-creative 
high-light the importance of value co-creation, i.e. services should be experienced through the eyes of all services stakeholders (including service users and service providers.

Sequencing means that services should be visualised as dynamic processes - a sequence of interrelated actions wherein each unique action can be delivered either by humans or ICT. Evidencing requires that service designers should strive to visualise intangible services in terms of physical artefacts in order to get a clear idea of the implications of alternative design solutions. Finally, holistic means that the entire environment of a service sequence should be considered, rather than individual touch points. In Service Design research, the principle of co-design has gained increased attention during the past years (Blomkvist 2015; Trischler 2014; Vargo \& Lusch 2008). Co-design implies that designers work together with users during the whole design process, i.e. both in early creativity phases as well as during implementation (Gulliksen et al. 2003; Yu \& Sangiorgi 2014). In Service Design, techniques such as touch points and customer journeys are commonly used in order to promote a holistic service view. Touch points represent different service encounters where interaction between the service provider (either a human or ICT) and the service consumer takes place. It is in such touch points value is generated and the service is experienced (Sampson \& Froehle 2006; Yu \& Sangiorgi 2014; Trischler 2014; Clatworthy 2013). An illustrative example of touch points is presented by Clatworthy (2013, p. 15): 'a bank's touch points include its physical buildings, website, physical printouts, self-service machines, bank cards, customer assistants, call centres, telephone assistance etc.'. A customer journey shows the service from the customers' viewpoint, often in the form of a series of interrelated touch points. This means that a customer journey can include multiple organisations (Følstad et al. 2014) as well as facilitating the establishment of new partnerships (Kankainen et al. 2012). As such, customer journeys can aid designers to understand the tangibility (evidencing) of the service consumers' experience and bring in a time perspective (sequencing) in SD (Matthews 2014).

Service Design is about designing service offerings that may or may not include digital elements and $\mathrm{Yu}$ and Sangiorgi (2014) point out that service touch points can be physical or digital. However the main idea behind Service Design is to combine manual and digital service in order to meet the needs and expectations of service users (Stickdorn, 2011), thus promoting innovation. When designing new services, it is important to pay attention to the service delivery process that enhances the value for the service consumers (Trott 2012), as well as the core service. In doing so, there is an ample opportunity for service designers to co-create value with customers, thus promoting innovative design of new services as well as redesign of existing services (Agarwal \& Selen 2009).

If we translate these core principles into prescriptive elements for digital service innovation we may consider:

- SD (service design) 1 - Originate from user needs, culture, circumstances when identifying, designing and implementing digital services

- SD 2 - Keep users in focus in order to think outside the box and across organisational borders

- SD 3 - Interact with users of services in order to enable value creation

- SD 4 - Focus on a holistic user perspective in order to facilitate and enable service innovation

- SD 5 - Make the intangible tangible by visualising types of results and parts of the process

- SD 6 - Maintain a holistic process view by (for example) combining manual and digital elements of service as required. 


\section{Open Innovation}

Chesbrough (2003) introduces open innovation as a new perspective for business development $-\mathrm{a}$ ' new imperative for creating and profiting from technology'. Open innovation describes an innovation style where companies work with technological developments both inside and outside the conventional boundaries of the firm, developing novel business models with intellectual property that may have several owners. There are various advantages to open strategies. Organisations with complementary expertise cooperate on projects to reduce development costs, and design innovators co-operate with researchers to have access to leading-edge technical advances and funding through research projects. The open innovation movement has also spawned a variety of innovation ideas and techniques including product platforming, idea competitions, collaborative product design and development, innovation networks, crowdsourcing and commons-based peer production. Chesbrough's account of open innovation (using openness principles to generate innovation) and open business models (generating value by sharing parts of your intellectual property) describes a variety of value generation strategies. He contrasts closed and open innovation principles like this (Chesbrough 2006):

\begin{tabular}{|l|l|}
\hline closed innovation principles & open innovation principles \\
\hline $\begin{array}{l}\text { the smart people in our field work } \\
\text { for us }\end{array}$ & $\begin{array}{l}\text { not all the smart people work for us - we need to } \\
\text { work with smart people inside and outside our } \\
\text { company }\end{array}$ \\
\hline $\begin{array}{l}\text { to profit from R+D. we must } \\
\text { discover it, develop it, and ship it } \\
\text { ourselves }\end{array}$ & $\begin{array}{l}\text { external R+D can create significant value - internal } \\
\text { R+D is needed to claim some portion of that value }\end{array}$ \\
\hline $\begin{array}{l}\text { if we discover it ourselves, we will } \\
\text { get it to market first }\end{array}$ & $\begin{array}{l}\text { we don't have to originate the research to profit from } \\
\text { it }\end{array}$ \\
\hline $\begin{array}{l}\text { the company that gets an } \\
\text { innovation to market first will win }\end{array}$ & $\begin{array}{l}\text { building a better business model is better than getting } \\
\text { to market first }\end{array}$ \\
\hline $\begin{array}{l}\text { if we create the most and the best } \\
\text { ideas in the industry, we will win }\end{array}$ & $\begin{array}{l}\text { if we make the best use of internal and external ideas, } \\
\text { we will win }\end{array}$ \\
\hline $\begin{array}{l}\text { we should control our IP, so that } \\
\text { our competitors don't profit from } \\
\text { our ideas }\end{array}$ & $\begin{array}{l}\text { we should profit from others' use of our IP, and we } \\
\text { should buy others' IP wherever it advances our } \\
\text { business model }\end{array}$ \\
\hline
\end{tabular}

Table 4. Closed and open innovation principles (Chesbrough 2006)

Chesbrough also applies open innovation ideas to the service concept (Chesbrough, 2010, Chesbrough, 2011), following in the wake of the service-dominant logic movement. He argues that businesses 'must change the way they approach innovation and growth ... to confront, and then to transcend, the commodity trap ... stop thinking like product manufacturers and start thinking about business from a services perspective ... think about their business from an open services perspective to discover new ways to generate profitable growth' (Chesbrough 2011). Companies should work closely with customers to develop new solutions, focus offers on utility, rather than the product, and embed themselves in their customer's organisation. His open service innovation framework requires managers to

1. Think of your business (whether a product or a service) as an open service business in order to create and sustain differentiation in a commodity trap world.

2. Invite customers to co-create innovation with you in order to generate the experiences they will value and reward 
3. Use open innovation to accelerate and deepen services innovation, making innovation less costly, less risky, and faster. Use open innovation to help you turn your business into a platform for others to build on.

4. Transform your business model with open services innovation, which will help you profit from your innovation activities. If you succeed in building a platform business model, you can also profit from others' innovation activities as well. In practice, it is difficult to maintain a closed innovation style (in which innovation is inhouse and intellectual property heavily defended) for digital services because all digital artefacts are easy to reproduce, modify, recombine and distribute without degrading their value (Jones \& Rose 2016). Open source projects can be exemplars for digital innovation (Lundell \& van der Linden 2012); in fact, open source is classed as a new innovation model by von Hippel and von Krogh (von Hippel \& von Krogh 2003): the private (not supported by the state) collective (open access) model. The collective is able to leverage the knowledge of many talented service designers in different roles and is often dependent on an innovative business model to generate revenue. There is a value in a community (for example shared knowledge, better feedback processes and dissemination, and free marketing). Integrated design communities offer domain knowledge, coding input, feedback, creative and work opportunities.

If we translate these considerations into prescriptive elements for digital service innovation we might get:

- OI (open innovation) 1 - Include innovation expertise from a variety of stakeholders including customers/citizens, partner companies or institutions, software firms, open source initiatives

- OI 2 - Borrow innovative ideas from outside, but identify and develop key parts of the service innovation that focus on the unique value proposition

- OI 3 - Establish how the service complements or develops the business or operations model

- OI 4 - Develop an integrated service platform focused on developing business needs

- OI 5 - Don't tightly control service provision in-house, instead use it as a platform for others to build on

- OI 6 - Understand the digital service in its organisational context as a whole, rather than focus on the digital component of it

- OI 7 - Involve the user of the digital service in its design

- OI 8 - Use the principles of open innovation to support design work

- OI 9 - Transform the entire value proposition of the digital service, rather than simply automating an existing manual service

\section{Service-Dominant Logic}

Ostrom et al. (2010) define service science "as an emerging interdisciplinary field of inquiry that focusses on fundamental science, models, theories, and applications to drive service innovation, competition, and wellbeing through co-creation of value." Thus, service science focuses on a shift from a goods-dominant (G-D) logic to a service-dominant logic (SDL). The service definition used within the field of service science is the one offered by S-D logic: "the application of specialized competences (knowledge and skills) through deeds, processes, and performances for the benefit of another entity or the entity itself" (Vargo \& Lusch 2004). This definition could be regarded as a reaction to the traditional service marketing perspective derived from the G-D logic (e.g. Vargo \& Lusch 2004; Edvardsson \& Tronvoll 2013; Grönroos 2011). From a G-D logic perspective services have been claimed to posit specific characteristics: heterogeneous, produced and consumed simultaneously, non- 
storable, and intangible (Zeithaml \& Berry 1985; Lovelock et al. 2014; Lovelock \& Wright 2001). These bear some resemblance to the characteristics of digital artefacts referred to in the previous section. In contrast to G-D logic, the focused concepts of SDL are resource integration (i.e. knowledge and skills), co-creation of value propositions and value exchange, which imply a service perspective rather than specific service characteristics. The SDL perspective redefines the role of the company, customer, and other actors in service ecosystems; thus S-D logic informs innovation differently from G-D logic (Lusch \& Nambisan 2015; Vargo \& Lusch 2008). From an SDL perspective, service innovation is defined as "re-bundling of diverse resources that create novel resources that are beneficial (i.e., value experiencing) to some actors in a given context; this almost always involves a network of actors, including the beneficiary (e.g., the customer)" (Lusch \& Nambisan 2015). This definition corresponds well with the contemporary view of innovation in the IS field where scholars argue that there is a shift toward less predefined and more distributed innovation agency where innovation occurs in collaboration in service ecosystems (Lusch \& Nambisan 2015; Nambisan et al. 2017; Lakhani \& Panetta 2007; Sawhney \& Prandelli 2000).

Nylén and Holmström (2015) provide a framework to support practitioners in their endeavours to innovate services. The framework suggests that practitioners should focus on user experience, value proposition, digital evolution scanning, skills, and improvisation. In the service science sector, Lusch and Vargo (Lusch \& Vargo 2006) provide some concrete service advice to practitioners. The scholars argue that firms should be transparent and make all information symmetric in the exchange process. Since the customer is a partner, anything other than complete truthfulness will not work. Practitioners should strive to develop good relationships with partners in their ecosystem, and, always look out for the best interests of the beneficiary (i.e. value proposition). Lusch and Vargo (2006) argue that operant resources and collaborative competence are primary determinants for acquiring knowledge for competitive advantage. That is, firms gain a competitive advantage by engaging customers and partners in co-creation and co-production activities; thus understanding how customers uniquely integrate and experience service-related resources is key to innovation (ibid). Information technology, which reduces communication and computation costs, provides firms with opportunities for increased competitive advantage through innovative collaboration. The value network member that is the prime integrator is in a stronger competitive position (ibid). Furthermore, in an attempt to summarise the essence of S-D logic, and establish a framework for a service-oriented mindset, Vargo and Lusch (Vargo \& Lusch 2004; Vargo \& Lusch 2008; Vargo \& Lusch 2016) have suggested eleven normative foundational premises (FP) (Table 5). S-D logic is built on excellent theoretical grounding but lacks empirical evidence (Cronholm et al. 2017).

\begin{tabular}{|l|l|}
\hline$F P$ & Description \\
\hline FP1 & Service is the fundamental basis of exchange. \\
\hline FP2 & Indirect exchange masks the fundamental basis of exchange. \\
\hline FP3 & Goods are a distribution mechanism for service provision. \\
\hline FP4 & Operant resources are the fundamental source of strategic benefit. \\
\hline FP5 & All economies are service economies. \\
\hline FP6 & Value is co-created by multiple actors, always including the beneficiary. \\
\hline FP7 & $\begin{array}{l}\text { Actors cannot deliver value but can participate in the creation and offering of } \\
\text { value propositions. }\end{array}$ \\
\hline FP8 & A service-centred view is inherently beneficiary oriented and relational. \\
\hline FP9 & All social and economic actors are resource integrators. \\
\hline FP10 & Value is always uniquely and phenomenologically determined by the beneficiary. \\
\hline
\end{tabular}


FP11 Value co-creation is coordinated through actor-generated institutions and institutional arrangements.

Table 5. The foundational premises of S-D logic (Vargo \& Lusch 2016)

According to Löbler and Lusch (2014), the service revolution and service innovation processes are inextricably linked to the IT revolution. The combination of digital resources with the adoption of an S-D logic perspective create enhanced opportunities for digital service innovation. However, the foundational principles are neither prescriptive not adapted for a digital service context. Moreover, the statements suggested by Lusch et al. (2007) and Lusch and Vargo (2006) are partly directed to the retailing sector and they are only normative in respect to the character of SDL. Hence, we argue that we need to better align service related premises and statements to the context of digital service. We derive seven prescriptions that could be used to shape theory-based design principles:

- SDL (Service-Dominant Logic) 1 - Actors should focus on operant resources (knowledge and skills) by making knowledge transparent, since operant resources are the fundamental sources of benefit and constitute a competitive advantage (Derived from FP1 and FP4 and Lusch and Vargo (2006))

- SDL 2 - Value should be co-created by multiple actors by collaborative work procedures since it will acquire the knowledge for competitive advantage (Derived from FP 6 and Lusch et al. (Lusch et al. 2007))

- SDL 3 - All actors should participate in the creation of value propositions (e.g. service innovations) by collaborative work procedures (Derived from FP7 and FP9)

- SDL 4 - All actors should foster institutional arrangements by shared routines, policies etc. because it will leverage the flow of resources between actors (Derived from FP11. FP9, and FP4)

- SDL 5 - Actors should foster competitive advantage by utilising information technology, and through innovative collaboration (Derived from FP6, FP8 and Lusch et al. (2007)).

- SDL 6 - Firms should work to understand how the customers uniquely integrate and experiences service-related resources and use the knowledge to co-create service innovations since that knowledge is a source of competitive advantage. (Derived from FP6, FP8, FP9 and Lusch et al. (2007)).

- SDL 7 Actors should treat their employees as operant resources though competence development since new knowledge and skills will gain competitive advantage. (Derived from FP4, and Lusch et al. (2007))

\section{Theoretical prescriptions summarised}

Table 6 summarises the 22 prescriptive statements derived from the kernel theory analysis. 


\begin{tabular}{|c|c|c|}
\hline Service design & Open innovation & Service-dominant logic \\
\hline $\begin{array}{l}\text { SD 1. Originate from user } \\
\text { needs, culture, } \\
\text { circumstances when } \\
\text { identifying, designing and } \\
\text { implementing digital } \\
\text { services }\end{array}$ & $\begin{array}{l}\text { OI 1. Include innovation } \\
\text { expertise from a variety of } \\
\text { stakeholders including } \\
\text { customers/citizens, partner } \\
\text { companies or institutions, } \\
\text { software firms, open source } \\
\text { initiatives }\end{array}$ & $\begin{array}{l}\text { SDL 1. Actors should focus on } \\
\text { operant resources (knowledge } \\
\text { and skills) by making } \\
\text { knowledge transparent, since } \\
\text { operant resources are the } \\
\text { fundamental sources of benefit } \\
\text { and constitute competitive } \\
\text { advantage }\end{array}$ \\
\hline $\begin{array}{l}\text { SD 2. Keep users in focus } \\
\text { in order to think outside } \\
\text { the box and across } \\
\text { organisational borders }\end{array}$ & $\begin{array}{l}\text { OI 2. Borrow innovative } \\
\text { ideas from outside, but } \\
\text { identify and develop key } \\
\text { parts of the service } \\
\text { innovation that focus on the } \\
\text { unique value proposition }\end{array}$ & $\begin{array}{l}\text { SDL } 2 \text {. Value should be co- } \\
\text { created by multiple actors by } \\
\text { collaborative work procedures } \\
\text { since it will acquire the } \\
\text { knowledge for competitive } \\
\text { advantage }\end{array}$ \\
\hline $\begin{array}{l}\text { SD 3. Interact with } \\
\text { consumers of services in } \\
\text { order to enable value } \\
\text { creation }\end{array}$ & $\begin{array}{l}\text { OI. 3. Establish how the } \\
\text { service complements or } \\
\text { develops the business or } \\
\text { operations model }\end{array}$ & $\begin{array}{l}\text { SDL 3. All actors should } \\
\text { participate in the creation of } \\
\text { value propositions (e.g. service } \\
\text { innovations) by collaborative } \\
\text { work procedures }\end{array}$ \\
\hline $\begin{array}{l}\text { SD } 4 \text {. Focus on a holistic } \\
\text { consumer perspective in } \\
\text { order to facilitate and } \\
\text { enable service innovation }\end{array}$ & $\begin{array}{l}\text { OI 4. Develop an integrated } \\
\text { service platform focused on } \\
\text { developing business needs }\end{array}$ & $\begin{array}{l}\text { SDL 4. All actors should foster } \\
\text { institutional arrangements by } \\
\text { shared routines, policies etc. } \\
\text { because it will leverage the } \\
\text { flow of resources between } \\
\text { actors }\end{array}$ \\
\hline $\begin{array}{l}\text { SD 5. Make the intangible } \\
\text { tangible by visualising } \\
\text { types of results and parts } \\
\text { of the process }\end{array}$ & $\begin{array}{l}\text { OI 5. Don't tightly control } \\
\text { service provision in-house, } \\
\text { instead use it as a platform } \\
\text { for others to build on }\end{array}$ & $\begin{array}{l}\text { SDL 5. Actors should foster } \\
\text { competitive advantage by } \\
\text { utilising information } \\
\text { technology and through } \\
\text { innovative collaboration }\end{array}$ \\
\hline $\begin{array}{l}\text { SD 6. Maintain a holistic } \\
\text { process view by (for } \\
\text { example) combining } \\
\text { manual and digital } \\
\text { elements of service as } \\
\text { required. }\end{array}$ & $\begin{array}{l}\text { OI } 6 \text {. Understand the digital } \\
\text { service in its organisational } \\
\text { context as a whole, rather } \\
\text { than focus on the digital } \\
\text { component of it }\end{array}$ & $\begin{array}{l}\text { SDL } 6 \text {. Firms should work to } \\
\text { understand how the customers } \\
\text { uniquely integrate and } \\
\text { experiences service-related } \\
\text { resources and use the } \\
\text { knowledge to co-create service } \\
\text { innovations since that } \\
\text { knowledge is a source of } \\
\text { competitive advantage. }\end{array}$ \\
\hline
\end{tabular}




\begin{tabular}{|l|l|l|}
\hline & $\begin{array}{l}\text { OI 7. Involve the user of the } \\
\text { digital service in its design }\end{array}$ & $\begin{array}{l}\text { SDL 7. Actors should treat } \\
\text { their employees as operant } \\
\text { resources though competence } \\
\text { development since new } \\
\text { knowledge and skills will gain } \\
\text { competitive advantage }\end{array}$ \\
\hline & $\begin{array}{l}\text { OI 8. Use the principles of } \\
\text { open innovation to support } \\
\text { design work }\end{array}$ & $\begin{array}{l}\text { OI 9. Transform the entire } \\
\text { value proposition of the } \\
\text { digital service, rather than } \\
\text { simply automating an } \\
\text { existing manual service }\end{array}$ \\
\hline
\end{tabular}

Table 6. Prescriptive elements summarising the theory bases.

\section{Refining and organising the theory elements}

In this section, we aim to synthesise an economical set of necessary and sufficient design principles from the core theory elements in Table 6 . Table 6 contains many elements which repeat or overlap each other, and some ideas which are contradictory, or outliers in the sense that they are not reflected in the other theory bodies. We used a further workshop and analysis to identify groupings, duplication and overlap in the prescriptive theory elements in Table 6 - places where the statements converge around common themes. The objective is to discover places where the three theory groups converge on common ideas, theoretical tenets and prescriptions. We also pay attention to the innovative digital services context and what is potentially useful for method design, as well as characteristic, procedure and argument which may contribute to the eventual design principles. Characteristic is usually given in convergence heading, and procedure (process) and arguments identified in the text. In further steps we identify outliers and contradictions between in the theory elements. The final step is to develop an economical set of design principles in the Van den Akker (1999) formulation which can be used (in this case) to guide method development work. The following theory convergences are identified.

\section{C (convergence) 1. Focus on customer needs}

A common focus on user/customer/consumer needs is expressed in SD1-3, OI 7 and SDL 6, which is also implied in SDL 1-5. The service design literature has a user-centred focus and a focus on co-design, where users and service developers work together in the design activity. Open innovation values the contribution of users in bringing specialised knowledge to the innovation process - for instance the contribution of virtual lead users (Mahr \& Lievens 2012). In service-dominant logic the user/customer is the beneficiary of the service, and their needs are paramount for strategic positioning. The process of involving users usually implies some form of participatory development (co-design). The argument for this focus is that service users are the ultimate determiners of the value of the service, and that other service actors are not as effective in anticipating their needs as users themselves. 


\section{C2. Identify service benefit}

All kernel theories express the need to identify the service value or benefit, sometimes expressed as the value proposition, particularly for the service user (SD 3, OI 2, OI 9, SDL 23). Service design understands value to as created during the customer journey at a series of service touchpoints. For open innovation, value is often specified through the business model, where the value proposition for customers is central. The innovation of the business model is more important than technological advances. SDL re-invents strategic benefit and competitive advantage for organisations through the focus on service. Though the process for identifying service value is sometimes unclear, the argument always takes the form: first target value for the service user, user value secondarily generates value for the service provider.

\section{C3. Treat the service holistically}

There is a frequently expressed need to think holistically to keep the whole service in view, including both digital and manual components (SD 4, SD 6, OI4, OI 6 and OI 9, and implied in SDL 4). In SD this is understood as visualising and making concrete user touchpoints along a customer journey, in OI as focusing on the business model (involving the complete service conception, rather than a digital update of an existing service) and in SDL in a wide interest in the integration of value networks and involving multiple actors and shared routines and policies. None of the theory bases is principally concerned with the digital implementation of services, but digital services generally have some manual components and require re-organisation of existing processes and routines. In the context of digital service innovation, thinking holistically helps to avoid trivial or non-functional updates of existing services - for instance posting a manual form to print out on a website. Again it is unclear how to do this, but the principle argument is that more value is obtained by rethinking the whole service, rather than digitising existing elements.

\section{C4. Design from an understanding of the service operation}

There is a widespread commitment to understanding the service processes, operations, business model, policies and routines, both in their existing form, and in their (re)designed forms (SD 5-6 and OI 3). SD focuses more on the design outcome, in terms of sequencing (understanding process chains) and evidencing (making parts of the service implementation concrete). OI suggests transforming the whole organisational business model with open service innovation, whereas SDL has a focus on operational routines, policies and institutional arrangements. The argument for this is again that digital service innovation impacts many aspects of organisations, which need to be realigned in order to generate value.

\section{C5. Co-creation}

There is a common emphasis on co-creation involving multiple stakeholders, both internal + external, expressed in OI 1 and SDL 1-6. Stakeholders may involve the commissioner of the service, internal actors who understand the organisational process, routines and requirements, various kinds of service designers and developers (including software experts designing and building the digital service components), as well as service users. Service design points out that the user experience (journey) may involve several organisations or departments, as in the example of a citizen interacting with multiple governmental agencies at a major life event. Open innovation is particularly concerned to gather creative ideas and domain expertise from outside the service commissioner's home organisation, including working closely with customers and partners. Service-dominant logic requires understanding the whole service eco-system, and co-creation with the value network. The process normally involves forms of collaborative work, co-design and co-production. The arguments are that value creation is 
larger and more complex than automating a manual process in a narrow organisational context, and that innovation requires the combination of various specialist competences.

\section{C6. Leverage knowledge and competence}

The last theory convergence is in the area of knowledge, competence and skills, especially when used for innovation (SDL 1-2, 6-7 and OI 1-2). These operant resources are of particular concern for SDL, and incorporating external and internal innovation competence and domain expertise is a principal focus for OI. As in other areas the implied process for leveraging knowledge is work collaboration, co-production and co-design. The argument is both in the role of knowledge in innovation, and in re-organisation around digital service for multiple actors.

\section{C7 Think innovatively (outside the box)}

A common focus on thinking and working innovatively (outside the box) is expressed in SD

2, OI 1-2 and SDL 5-6. Innovation in service design theory involves thinking across organisational borders and originating from user culture. In open innovation it requires internal and external knowledge and competence, and a focus on those components of the service that impact the value proposition. Knowledge and competence in the form of operant resources are also the principal source of innovation in service-dominant logic. In the digital service context, the argument for thinking innovatively is that digital technologies bring new possibilities for delivering service; however for OI and SDL the argument is more concerned with developing and sustaining competitive advantage, and differentiating service offerings from those of competitors.

In addition to these theory convergences, we can identify some outliers and contradictions in the theory prescriptions expressed in Table 6. Open innovation employs some platform thinking (OI 5): the service can operate as a digital platform (in the manner of an online app store). Part of the value of a digital service here lies in what external service developers can tie in, or add to the existing service. This could also align with SDL thinking on value networks, but the connections are not very explicit and we elected not to pursue it further. We also dropped SDL 7 which focuses on employee competence development which is not heavily echoed in the other theory bases. Both OI and SDL are general business arena theories with strong private sector orientation, and employing the language of business strategy. SD is more neutral in this respect, and since we understand digital service innovation to be equally relevant to public sector organisations we made a conscious decision to use sector neutral formulations - for instance we might prefer to focus on the formulation 'value' rather than 'competitive advantage' since the latter has no clear equivalent in the public sector. SD is more focused on the process of design, where tools, methods and techniques are never far from view. However though OI 8 specifies that the principles of open innovation should support design work, it's not clear how this should happen in practice and Chesbrough does not provide specific design tools, method or method fragments which would enable this. We conclude that this might be a gap that we, as future method designers, might fill.

\section{Six design principles for building an innovative service design method}

In this section, we define the finalised design principles by integrating the convergences in the previous section. We avoid outliers and contradictions. We also pay attention to the context of innovative digital services, and the eventual purpose of the principles - guiding method design. In some cases the connections are obvious, for instance Convergence 1. 
Focus on customer need relates directly to design principle 1. Value is determined by the beneficiaries. In other cases several convergences are merged in one design principle; $C 5$. Co-creation, C6. Leverage knowledge and competence, and C7 Think innovatively are reflected in Design Principle 6. innovation through openness (principally in the form of knowledge sharing) in the design and development process. In each case the relationships are noted in the heading. In addition we translate the design principles into the Van den Akker (1999) formulation: 'if you want to design intervention $\mathrm{X}$ (for the purpose/function $\mathrm{Y}$ in context $\mathrm{Z}$ ), then you are best advised to give that intervention the characteristics $\mathrm{A}, \mathrm{B}$, and $\mathrm{C}$ (substantive emphasis), and to do that via procedures $\mathrm{K}$, L, and $\mathrm{M}$ (procedural emphasis), because of arguments P, Q, and R.' Characteristics, procedures (process) and arguments are noted in the convergence texts in the previous section.

If you want to design a method for digital service innovation (common for all design principles) -

Design Principle 1 (see C1, C5)

- then you are best advised to give that intervention the characteristic: value is determined by the beneficiaries (service consumers)

and to do that via procedure: co-creation by stakeholders including beneficiaries

because of arguments:

1) value is always uniquely determined by the beneficiary, and

2) actors cannot deliver value but can participate in the creation and offering of value propositions

Design Principle 2 (see C2)

- then you are best advised to give that intervention the characteristic: competitive advantage and strategic benefit (public value)

and to do that via procedure: use operant resources (knowledge and skill) as the primary perspective

because of the arguments

1) operant resources are the fundamental source of strategic benefit, and constitute competitive advantage

2) service is the primary driver for value, even where the exchange of goods or information is involved

Design Principle 3 (see C3, C5, C4, C6)

- then you are best advised to give that intervention the characteristic: all necessary resources in the service ecosystem are integrated

and to do that via procedure: promote actor-generated institutions and institutional arrangements.

because of argument: service is relational and shared knowledge will increase value propositions

Design Principle 4 (see C3, C1)

- then you are best advised to give that intervention the characteristic: service should appear as an integrated package to the beneficiary, reflecting their life situation and interests and how they may be improved and to do that via procedure: adopt a user-centred design approach where the interactions between service and beneficiaries drive the design 
because of argument: value is determined from the perspective of the service beneficiaries within their own developing life situation

\section{Design Principle 5 (see C2, C3, C4)}

- then you are best advised to give that intervention the characteristic: delivery of the service is an integrated digital and manual process with improved value for the beneficiaries as its output

and to do that via procedure: transform the entire value proposition of the digital service, rather than simply automating the existing manual service

because of argument: innovation (transformation) depends on both the digital innovation and the business model

Design Principle 6 (see C5, C6, C7)

- then you are best advised to give that intervention the characteristic: innovation through openness (principally in the form of knowledge sharing) in the design and development process

and to do that via procedure: leverage the knowledge and innovation competences of various internal and external stakeholders in the service development

because of argument: innovation benefits from sharing of different forms of expert knowledge.

\section{Conclusions}

This article set out to construct theory-based design principles, which could provide the theoretical foundation for new methods for the development of innovative digital services, in the context of a wider research project focused on method design in the area of innovative digital services. The study offers two primary contributions, the first being the six design principles, and the second being an illustration of how design principles can be grounded in kernel theory in a transparent and recoverable way. We used a four-step research process designed for the purpose. We formulated a set of five solution objectives, identified service design, open innovation and service-dominant logic as kernel theories, and derived 22 prescriptive and normative elements from the seminal authors we investigated. The result of the process was a set of six theory-based design principles, articulated in a predetermined logical formulation. There was also empirical feedback from participating practitioner partners along the way, but we chose to present a primarily theoretical argument here. We overcame a number of challenges: there are many relevant theories, many contributors, many different aspects of these contributions that could be relevant, and various types of theory involved, not all of it obviously normative, and none of it developed as kernel theory for design science. As in any predominantly theoretical discussion, any link in our chain of argument can be disputed (but hopefully not disproved), and the contribution lies in the design principle output, backed by a well-constructed argument. The structure of the paper is designed to make the argument traceable and reproducible. A limitation of our set of principles is that the kernel theories are better targeted at conceptual design and early-stage requirements work, and very poorly targeted at detailed technical design work. It's also taken for granted that the selection of different kernel theories might result in different design principles.

The benefits for practitioners primarily lie in the future, with the development of practice-oriented method components sketched in the previous section, whereas researchers can use this contribution in two different ways. They can use our design principles as support for design science artefacts (or adapt them for related tasks in similar areas). They may also 
study the process of developing design principles from theory as an exemplar for similar tasks in different areas of theory with different design goals. The focus of this paper has been on constructing a set of necessary and sufficient theory-based design principles. We are currently working on building method tools based on the principles, including versions of the well-known business model canvas (Osterwalder \& Pigneur 2010) targeted at innovative digital service design. Future research might also consider other aspects of digital services, such as evaluation and feedback, communicating them to potential users, and different kinds of partnerships between service providers.

Acknowledgement: The research was supported by Västra Götaland through the TIKT project Innoserve

\section{References}

Agarwal, R. \& Selen, W., 2009. Dynamic Capability Building in Service Value Networks for Achieving Service Innovation. Decision Sciences, 40(3), pp.431-475.

Van den Akker, J., 1999. Principles and methods of development research. In J. J. H. van den Akker et al., eds. Design approaches and tools in education and training. Boston, MA: Kluwer Academic Publishers, pp. 1-14.

Barrett, M. et al., 2015. Service innovation in the digital age: Key contributions and future directions. MIS Quarterly, 39(1), pp.135-154.

Berry, L.L. \& Lampo, S.K., 2000. Teaching an old service new tricks: The promise of service redesign. Journal of Service Research, 2(3), pp.265-275.

Blomkvist, J., 2015. Ways of seeing service: Surrogates for a design material. Nordic Design Research Conference, 6.

Chesbrough, H., 2006. Open business models: How to thrive in the new innovation landscape, Boston, MA: Harvard Business Press.

Chesbrough, H., 2003. Open Innovation: The New Imperative for Creating and Profiting from Technology, Boston, MA: Harvard Business School Publishing.

Chesbrough, H., 2011. Open Services Innovation: Rethinking Your Business to Grow and Compete in a New Era, San Francisco: Jossey-Bass.

Clatworthy, S., 2013. Design support at the front end of the New Service Development (NSD) process. Oslo school of Architecture and Design.

Coreynen, W. et al., 2017. Internal levers for servitization: How product-oriented manufacturers can upscale product-service systems. International Journal of Production Research, pp.1-15.

Cronholm, S. et al., 2017. IT Service Management: The Alignment of ITIL Practitioner with Service-Dominant Logic. In Australasian Conference on Information Systems. Hobart.

Cronholm, S. \& Göbel, H., 2017. ITIL Compliance with a Service Perspective: a Review Based on Service-Dominant Logic. In 27th Australasian Conference on Information Systems. Wollongong, Australia.

Edvardsson, B. \& Tronvoll, B., 2013. A new conceptualization of service innovation grounded in S-D logic and service systems. International Journal of Quality and Service Sciences, 5(1), pp.19-31.

Følstad, A., Kvale, K. \& Halvorsrud, R., 2014. Customer journeys: Involving customers and internal resources in the design and management of services S. 2014, ed. Fourth Service Design and Innovation Conference "Service Futures."

Gregor, S., 2002. Design theory in information systems. Australasian Journal of Information Systems, 10(1), pp.14-22.

Gregor, S. \& Hevner, A.R., 2013. Positioning and Presenting Types of Knowledge in Design Science Research. MIS Quarterly, 37(2), pp.337-355. 
Gregor, S. \& Jones, D., 2007. The Anatomy of a Design Theory. Journal of the Association for Information Systems, 8(5), pp.312-335.

Grönroos, C., 2011. Value co-creation in service logic: a critical analysis. Marketing Theory, 11(3), pp.279-301.

Gulliksen, J. et al., 2003. Key principles for user-centred systems design. Behaviour \& Information Technology, 226(6), pp.397-409.

Heinrich, P. \& Schwabe, G., 2014. Communicating nascent design theories on innovative information systems through multi-grounded design principles. In International Conference on Design Science Research in Information Systems. Springer, pp. 148-163.

von Hippel, E. \& von Krogh, G., 2003. Open source software and the "private-collective" innovation model: Issues for organization science. Organization Science, 14(2), pp.209223.

Janowski, T., 2015. Digital government evolution: From transformation to contextualization. Government Information Quarterly, 32(3), pp.221-236.

Jones, M. \& Rose, J., 2016. Digital all the way down; innovation in the software industry H. Berends et al., eds. FEWEB Digital Innovation Workshop: Organizing for Digital Innovation.

Kankainen, A. et al., 2012. Storytelling Group - a co-design method for service design. Behaviour \& Information Technology, 31(3), pp.221-230.

Lakhani, K.R. \& Panetta, J.A.., 2007. The Principles of Distributed Innovation. Innovations , 2(3), pp.97-112.

Löbler, H. \& Lusch, R.F., 2014. Signs and Practices as Resources in IT-Related Service Innovation. Service Science, 6(3), pp.190-205.

Lovelock, C.H., Patterson, P. \& Wirtz, J., 2014. Services Marketing, Melbourne: Pearson.

Lovelock, C.H. \& Wright, L., 2001. Principles of Service Marketing and Management 2nd ed., Prentice Hall PTR.

Lundell, B. \& van der Linden, F., 2012. Open Source Software as Open Innovation: Experiences from the Medical Domain. In J. S. Z. Eriksson Lundström et al., eds. Managing open innovation technologies. New York: Springer, pp. 3-16.

Lusch, R. \& Vargo, S., 2006. Service-dominant logic as a foundation for a general theory A. M. E. Sharpe, ed., NY.

Lusch, R.F. \& Nambisan, S., 2015. Service Innovation: a Service-Dominant Logic Perspective. MIS Quarterly, 39(1), pp.155-176.

Lusch, R.F., Vargo, S.L. \& O’Brien, M., 2007. Competing through services: Insights from service-dominant logic. Journal of Retailing, 83(1), pp.5-18.

Mahr, D. \& Lievens, A., 2012. Virtual lead user communities: Drivers of knowledge creation for innovation. Research Policy, 41(1), pp.167-177.

March, S.T. \& Smith, G., 1995. Design and natural science research on information technology. Decision Support Systems, 15(4), pp.251-266.

Marti, P. \& Bannon, L.J., 2009. Exploring User-Centred Design in Practice: Some Caveats. Knowledge, Technology \& Policy, 22(1), pp.7-15.

Matthews, T., 2014. Sacred Services: How can knowledge from social science relating to the sacred inform the design of service experiences? Artifact, 3(2), p.6.1-6.9.

Miller, S.E., 1993. From Systems Design to Democracy. Communications of the ACM, 36(4), p.38.

Nambisan, S. et al., 2017. Digital innovation management: Reinventing Innovation management research in a digital world. MIS Quarterly, 41(1), pp.223-238.

Nylén, D. \& Holmström, J., 2015. Digital innovation strategy: A framework for diagnosing and improving digital product and service innovation. Business Horizons, 58(1), pp.5767. 
Osterwalder, A. \& Pigneur, Y., 2010. Business Model Generation, Hoboken, New Jersey: Wiley.

Ostrom, A.L. et al., 2010. Moving forward and making a difference: research priorities for the science of service. Journal of Service Research, 13(1), pp.4-36.

Rose, J. et al., A process for deriving theory-based design principles. European Journal of Business Research Methods, in review.

Rose, J., 2010. Software Innovation: eight work-style heuristics for creative system developers, Aalborg, Denmark: Software Innovation.

Sampson, S.E. \& Froehle, C.M., 2006. Foundations and Implications of a Proposed Unified Services Theory. Production and Operations Management, 15(2), pp.329-343.

Sawhney, M. \& Prandelli, E., 2000. Communities of Creation: Managing Distributed Innovation in Turbulent Markets. California Management Review , 42(4), pp.24-54.

Sein, M.K. et al., 2011. Action design research. MIS Quarterly, 30(3), pp.611-642.

Stickdorn, M. \& Schneider, J., 2012. 5 Principles of Service Design Thinking.pdf. In M. Stickdorn \& J. Schneider, eds. This Is Service Design Thinking: Basics, Tools, Cases. New Jersey: Wiley \& Sons, pp. 34-45.

Trischler, J., 2014. User involvement in service design teams - investigating the effect of involving users in ideation of library services. Southern Cross University.

Trott, P., 2012. Innovation management and new product development, Essex: Pearson.

Vargo, S.L. \& Lusch, R.F., 2004. Evolving to a New Dominant Logic for Marketing. Journal of Marketing, 68(1), pp.1-17.

Vargo, S.L. \& Lusch, R.F., 2016. Institutions and axioms: an extension and update of servicedominant logic. Journal of the Academy of Marketing Science, 44(1), pp.5-23.

Vargo, S.L. \& Lusch, R.F., 2008. Service-dominant logic: Continuing the evolution. Journal of the Academy of Marketing Science, 36(1), pp.1-10.

Walls, J.G., Widmeyer, G.R. \& El Sawy, O.A., 1992. Building an Information Systems Design Theory for Vigilant EIS. Information Systems Research, 3(1), pp.36-59.

Yu, E. \& Sangiorgi, D., 2014. Service design as an approach to new service development:reflections and futures studies S. 2014, ed. Fourth Service Design and Innovation Conference "Service Futures."

Zeithaml, A.P. \& Berry, L.L., 1985. Problems and Strategies in Services Marketing. Journal of Marketing, Vol. 49(Spring), pp.33-46. 